\title{
The mystery of high performance - mediation by entrepreneurial orientation and organizational citizenship behavior
}

\author{
Przemysław Zbierowski
}

\begin{abstract}
The search for high performance is one of the leading themes in management science with a number of frameworks developed over the decades. The purpose of the paper is to investigate if the effect of high performance organization (HPO) characteristics has a direct effect on actual organizational performance or if the effect is mediated by organizational citizenship behavior (OCB) and entrepreneurial orientation (EO). Previous research states that the framework of HPO characteristics answers the question of 'what' high performers do, but does not answer the question of 'how' they do it, suggesting a mediating effect. The study attempts to establish which of the pair of OCB and EO (if any) has a stronger mediating effect. The hypotheses were tested using a cross-sectional research design with a random and representative sample of 406 enterprises. The research was carried out using the technique of personal interview (CAPI). Established scales were used to measure high performance indicators, organizational citizenship behavior, entrepreneurial orientation, and organizational performance. The conceptual framework with mediated effects was tested using astructural equations modeling approach. Research results indicate that there is a strong direct positive relationship between high performance indicators and organizational effectiveness. Moreover, there is a strong positive effect of high performance indicators on entrepreneurial orientation and organizational citizenship behavior. However, the effect of those two constructs on organizational effectiveness is rather weak, and, in the case of $O C B$, negative. That leads to the conclusion that the direct effect of high performance indicators is stronger, although the positive mediation by entrepreneurial orientation is statistically significant. The study contributes to the scientific debate in at least three ways. First, it confirms that high performance characteristics have a strong effect on actual performance. Second, it points to entrepreneurial orientation

1 Przemysław Zbierowski, Ph.D., Associate Professor, Faculty of Economics, Department of HRM, University of Economics in Katowice, ul. 1-go Maja 50, 40-287 Katowice, Poland, e-mail: przemyslaw.zbierowski@ue.katowice.pl (ORCID ID: 00000001-6144-194).
\end{abstract}

Received 12 November 2018; Revised 24 March 2019, 17 May 2019; Accepted 9 September 2019.

This is an open access article under the CC BY license (https://creativecommons.org/licenses/by/4.0/legalcode). 
as a partial mediator in that relationship. Finally, it uncovers the very strong effect of high performance characteristics on organizational citizenship behavior. The research results also allow one to formulate practical recommendations. They mainly consider enhancing $O C B, E O$, and performance by skillful use of high performance factors. The study is novel in its approach to use OCB and entrepreneurial orientation as mediators in the effect of high performance characteristics on organizational performance, as no such attempts were made in the past.

Keywords: high performance indicators, entrepreneurial orientation, organizational citizenship behavior

\section{INTRODUCTION}

High organizational performance is one of the ultimate results that are investigated in management science. Scholars and practitioners have tried for decades to unlock the mystery of extraordinary outcomes and answer the question of why some organizations are extremely successful while others fail. One of the most coherent frameworks of high performance indicators has been presented by De Waal (2012). However, it only answers the question 'what' high performers do to be successful and not 'how' they do it. Therefore, current study is placed in the research stream that attempts to uncover the mechanism underlying the activities of market leaders. In practical terms, there is a mediated effect suggested between high performance factors and the actual achieved performance. The present study argues that much explanation in that regard could be proposed by another dynamic research notion - positive organizational scholarship. It draws attention to phenomena that are normatively positive and extraordinarily effective. The research stream provides another possible way of investigation in this regard on entrepreneurship, especially organizational entrepreneurship. Therefore, two ways of thinking of mediation are competitive - positive vs. entrepreneurial. The current study focuses on two possible mediators: entrepreneurial orientation (EO) and organizational citizenship behavior (OCB). The former was chosen because it is the most commonly used conceptualization and operationalization of organizational entrepreneurship. The choice of the latter is more complex. It reflects a positive way of organizational behavior in the most comprehensive way and encompasses five various aspects of positivity. The purpose of the paper is to establish which (if any) of those two phenomena mediate the relationship between high performance indicators and organizational performance in a stronger way. Therefore, the main research question is: 
$R Q$ : How do organizations achieve high performance and how do they use $O C B$ and $E O$ in that process?

Research results indicate that there is a strong direct positive relationship between high performance indicators and organizational effectiveness. Moreover, there is a strong positive effect of high performance indicators on entrepreneurial orientation and organizational citizenship behavior. However, the effect of those two constructs on organizational effectiveness is rather weak, and, in the case of $\mathrm{OCB}$, negative. That leads to the conclusion that the direct effect of high performance indicators is stronger, although the positive mediation by entrepreneurial orientation is statistically significant.

The study contributes to the scientific debate in at least three ways. It confirms that high performance characteristics have a strong effect on actual performance, it points to entrepreneurial orientation as a part mediator in that relationship, and it uncovers a very strong effect of high performance characteristics on organizational citizenship behavior. The study is novel in its approach to use OCB and entrepreneurial orientation as mediators in the effect of high performance characteristics on organizational performance, as no such attempts were made in the past.

\section{LITERATURE REVIEW AND HYPOTHESIS DEVELOPMENT}

\section{High performance organization}

The beginning of the notion of the high performance organization dates back to the early 1980s. Perhaps the first publication that can be placed within that notion is the work by Peters and Waterman (1982). It describes the behaviors of the most successful American companies. The study discovered that they share a couple of common phenomena: action orientation, being close to the customer, autonomy and entrepreneurship, productivity thanks to employees, strong values, clear profile of activity, simple form and low employment, and reconciling the contradiction between centralizing and decentralizing. Moreover, the key highlighted aspect is organizational alignment. They propose a framework of seven organizational components named McKinsey 7S. According to this framework, the organization might be successful only if all seven components (strategy, structure, systems, staff, style, skills, and shared values) are properly aligned with each other and with the external environment (strategy is the element that allows the organization to align itself with the outside world). 
Other significant contributions to the notion that need to be mentioned are by Collins and Porras (1994) and Collins (2001), who state that there are nine factors that distinguish leaders from other companies: continuity and change, key values and mobilizing goals, stability and non-linearity, 'cult' culture and specific people, consequence and innovations, discipline and creativity, systematic methods and experimental approaches, meaning and achievements, maintaining the core activities and stimulation of growth. The notion of the high performance organization was later continued by Holbeche (2005), Light (2005), Miller and Le Breton-Miller (2005), Lawler and Worley (2006). For instance, Light (2005) presents a list of four main traits of successful organizations: (1) alertness achieved by thinking in future terms, (2) agility in empowering members of the organization achieved by supporting communication and organizing, (3) adaptation achieved by building freedom in learning and imagination, using all available measures to avoid a lack of precision, (4) alignment achieved by leading towards vision and mission. On the other hand, Holbeche (2005) states that the main trigger of organizational development is the reconciliation of contradicting factors in the pursuit of creating dynamic stability and permanent success by managing change.

All of the above considerations are, however, not methodologically robust, and they lack a clear methodological approach. Moreover, the considerations of various authors are not consistent in their approaches, which makes it difficult to compare the results of their research (Peters \& Waterman, 1982; Collins \& Porras, 1994). The above limitations were taken into consideration by De Waal (2012), who proposed a coherent framework of 35 high performance indicators grouped within five high performance factors that are described below.

'Continuous improvement' includes adopting the strategy that sets the organization apart from others. Moreover, the organization makes a constant effort to develop, and the organization's processes are continuously improved, simplified, and aligned. For continuous improvement, it is also important that everything that matters to performance is explicitly reported, and both financial and non-financial information is reported to organizational members (De Waal, 2012, p. 34). To achieve continuous improvement, it is important to constantly innovate, and high performers continuously innovate their competencies, products, processes, and services (De Waal, van Nierop, \& Sloot, 2017).

'Openness and action orientation' is the factor that stresses the constant drive towards activity and performance (De Waal, 2010, p. 87). For that reason, the whole organization must be performance-driven. It is based on a frequent dialogue of the management with the employees. Organizational members spend much time on communication, knowledge exchange, and learning. Moreover, they are always involved in important processes. 
Openness and action orientation also require a particular style from the management (De Waal \& Heijtel, 2017). Managers must allow employees to make mistakes and welcome change.

The style of leadership is more broadly described in the factor 'management quality'. In high performing organizations, leaders have integrity, and they are role models for organizational members (De Waal, 2012, p. 33). Moreover, they are fast, both in decision making and taking the necessary action. Leaders are very effective, but they also focus on achieving results and coach organizational members to do the same. Leaders are also decisive with regard to non-performers (De Waal, van Nierop, \& Sloot, 2017). Leadership in high performing organizations is strong, and their leaders are confident and are trusted by organizational members.

Management quality is also reflected in 'workforce quality' (De Waal \& Meingast, 2017). That is achieved by holding organizational members responsible for their results. Management inspires organizational members to accomplish extraordinary results, organizational members are trained to be resilient and flexible, and the organization has a diverse and complementary workforce (De Waal \& Heijtel, 2017).

Finally, highly performing organizations are oriented at being successful in the long run (De Waal, 2012). That is achieved in several ways. High performers maintain good and long-term relationships with all stakeholders (De Waal \& Meingast, 2017). They are aimed at servicing their customers as effectively as possible. The organization grows through partnerships with suppliers and customers (De Waal, Mroueh, \& Schiavo, 2017). Long-term orientation is also achieved by a specific approach to human resource management. It aims at keeping managers and employees in the organization for a long time, which makes it a secure workplace for organizational members (De Waal \& Heijtel, 2017). Moreover, new managers are, in most cases, promoted from within the organization rather than being hired from the outside (De Waal, van Nierop, \& Sloot, 2017).

The strength of the De Waal's (2012) construct is that it has been very carefully conceptualized and operationalized. It was also tested in many research projects in an international context. De Waal (2012) tested it on a sample of 1470 enterprises from a couple of countries. He proves that the framework is independent of a national context. More recently, the framework was tested in many other countries, for instance, in the Arab world (De Waal, Mroueh, \& Schiavo, 2017). Moreover, the construct has also been tested in many industries, for instance, farming (De Waal \& Meingast, 2018). All of the research conducted proves that the framework might be applied to a variety of contexts. All of the above, and many other papers by 
De Waal and colleagues demonstrate that high performance indicators result in higher performance, therefore it can be hypothesized:

H1. High performance indicators positively influence organizational performance.

\section{Entrepreneurial orientation}

The base assumption for the entrepreneurial orientation (EO) scale is that entrepreneurial firms differ from other types of firms. They tend to take more risks than other types of firms, proactively search for new business opportunities and have a strong emphasis on new product innovation (Khandwalla, 1977; Miller \& Friesen, 1982; Mintzberg, 1973). Some researchers operationalized the behavior of entrepreneurial firms as consisting of product-market innovation, proactiveness of decisionmaking, and risk-taking. They maintained that the level of entrepreneurship presented by a firm was the aggregate total of these three sub-dimensions: "the extent to which top managers are inclined to take business-related risks (the risk-taking dimension), to favor change and innovation in order to obtain a competitive advantage for their firm (the innovative dimension), and to compete aggressively with other firms (the proactive dimension)" (Covin \& Slevin, 1988, p. 218) These scholars also argued that a firm that was truly entrepreneurial should exhibit high levels of each dimension. Some researchers even consider aggressive behavior toward competitors as a dimension of EO that is separate from proactiveness (Zarei, 2017). Freiling and Schelhow (2014) propose a meta dimension of EO (system exploitation) composed of two dimensions (coordination and arbitrage).

The idea that innovativeness is the fundamental undertaking of EO was first raised by Schumpeter (1934). Innovation is evidenced here by the creation and development of new products and processes. In contemporary research in the field, innovation is always put at the very heart of entrepreneurship. Lumpkin and Dess define entrepreneurial innovation as "the willingness to support creativity and experimentation in introducing new products/ services, and novelty, technological leadership and R\&D in developing new processes" (2001, p. 431). Innovation is sometimes used as the sole indicator of entrepreneurship in a way that only innovative firms are considered entrepreneurial. Some researchers stress that without innovation, there is no corporate entrepreneurship.

Also, the concept of risk-taking has long been closely associated with entrepreneurship. Even in the 19th century, John Stuart Mill argued that risktaking was the attribute of entrepreneurs. The idea of propensity to take risk 
as a core element of entrepreneurship gained support during the 20th century. Entrepreneurship used to be defined as activity centered on the willingness to engage in calculated business-related risks (Brockhaus, 1980). Nowadays, no researchers oppose the notion that every entrepreneurial activity involves taking risk. Moreover, entrepreneurs don't perceive themselves as taking more risk than average. They tend to categorize business situations as possessing less risk than non-entrepreneurs (Palich \& Bagby, 1995; Busenitz, 1999).

The concept of proactiveness received less attention from entrepreneurial scholars compared to the other two dimensions of entrepreneurial orientation. Researchers present different approaches and different definitions of proactiveness. Knight (1997) understood proactiveness as aggressive execution and follow through, driving toward achievement of the firm's objectives by whatever reasonable means are necessary. This aggressive behavior may be directed at rival firms. Stevenson and Jarillo (1990) conceptualized proactiveness as the organizational pursuit of business opportunities that were deemed by the firm to be positive or favorable. Similarly, Lumpkin and Dess view proactiveness as an "opportunity-seeking, forward-looking perspective involving introducing new products or services ahead of the competition and acting in anticipation of future demand to create change and shape the environment" (2001, p. 431).

The most widely used operationalization of an entrepreneurial orientation construct comes from Covin and Slevin (1989), based on Khandwalla (1977) and Miller and Friesen (1982). They stated that innovativeness, proactiveness, and risk-taking act together, creating a unidimensional strategic orientation and should be aggregated together. This assumption and the operationalization itself proved reliable and valid in many studies. However, later works raised concern pertaining to the dimensionality of the measure and the independence of the sub-dimensions (Dess, Lumpkin, \& McGee, 1999; Lumpkin \& Dess, 1996; Zahra, 1993). As opposed to a uni-dimensional measure constructed by Covin and Slevin (1989), a multi-dimensional measure, reflecting each of the sub-dimensions, was proposed (e.g., Lumpkin \& Dess, 1996). Proponents of a later approach argued that each sub-dimension of an EO construct uniquely contributes to the entrepreneurial process. They highlight the potential of each subdimension to have a different impact on key outcome variables such as firm performance (Lumpkin \& Dess, 2001).

Another critical issue concerning entrepreneurial orientation is its validity for research in different countries. Formerly, the constructs used were developed originally for studies in the United States and then utilized for research in international entrepreneurship without adequately examining their validity. Steensma, Marino, Weaver, and Dickson (2000) found that 
contemporary management theories may not be applicable in all international research contexts due to differences in national culture. Following this concern, Kreiser, Marino, and Weaver (2002) employed a multi-country sample to explore the cross-cultural validity of an EO construct. Their study provided strong support for the cross-cultural validity of this scale.

The relationship between high performance indicators and EO was tested and proven by Zbierowski (2012). The EO dimension that is to the greatest extent under the influence of HPO factors is innovativeness, especially in the context of continuous improvement of processes and constantly introduced innovations in products, services, and processes. Similarly, proactiveness is also under the influence of continuous improvement, but also openness and action orientation. Also, Jiang, Mao, Liu, and Zhao (2012) prove that organizational entrepreneurship mediates the relationship between high performance work systems and organizational performance. To sum up, even though the literature evidence is scarce, it can be hypothesized that:

H2. High performance indicators positively influence entrepreneurial orientation.

There is plenty of evidence that entrepreneurial orientation is positively linked to organizational performance, just to mention Covin and Slevin (1991), Zahra (1993), Lumpkin and Dess (1996), Wiklund and Shepherd (2005) as the most famous. Therefore, it can be hypothesized:

H3. Entrepreneurial orientation positively influences organizational performance.

Hypotheses $\mathrm{H} 2$ and $\mathrm{H} 3$ taken together allow one to assume that entrepreneurial orientation is a mediator in the relationship between high performance indicators and organizational performance, therefore:

H4. Entrepreneurial orientation mediates the relationship between high performance indicators and organizational performance.

\section{Organizational citizenship behaviors}

Organizational citizenship behaviors (OCB), also called prosocial work behaviors, are behaviors aimed at providing help or benefit to others (Cameron, Dutton, \& Quinn, 2003). The essential part of this kind of behavior is exceeding standard work roles and expectations and being grounded in altruistic assumptions on the intrinsic need to help another person, although the authentic motivation 
for OCB is still a matter of scholarly discussion. Organ (1998), who is considered to be the founder of organizational citizenship behavior, presents its frames and components. According to him, OCBs are "behaviors of a discretionary nature that are not part of formal requirements presented to employees, but nevertheless contribute to the effective functioning of the organization" (1988, p. 4). Organizational citizenship behaviors go beyond the work role but have organizational consequences. It is, however, essential to differentiate OCB from organizational prosocial behaviors that are aimed at improving the well-being of an individual, group, or organization (Brief \& Motowidlo, 1986) but might not be related to the organization itself.

Organ (1988) highlights three important aspects of organizational citizenship behaviors: (1) they are not formally recognized by a remuneration system, are not part of a job description, are performed in a fully discretionary manner based on an employee's personal choice, (2) they go beyond what can be coerced from the employees based on their job description, (3) they positively contribute to the performance of other employees and, consequently, to the performance of the whole organization. There is an ongoing debate on the degree of discretionarity of OCB. Some scholars claim that they might not be as altruistic as expected, and part of the motivation might be related to expected reciprocity according to social exchange theory. Also, the assumption that is exceeding the job description is criticized. Organ himself (1997) decided to revise that assumption due to the development of organizational procedures towards creating more general job roles instead of detailed and specific job descriptions. Organ (1988) also presents a five-dimensional model of organizational citizenship behavior with the following dimensions:

1) Altruism - discretionary behaviors that aim to result in helping another person to perform an organizationally important task or solving an organizationally important problem. Altruistic behaviors might be limited to an internal organizational context, but may also go beyond organizational borders and be directed at the outside world. Moreover, in most cases, there is no direct relation between such behaviors and benefits for the organization. It is assumed that cumulated altruistic behaviors contribute to higher performance in the long-run.

2) Conscientiousness - discretionary employee behaviors which go beyond the minimal requirements of the job description. They may relate to a lack of absenteeism, obeying the rules, breaks at work, etc. They indicate that the employee accepts and submits to all regulations at the organization.

3) Civic virtue - behaviors that indicate the deep concern of the employee towards organizational life and his or her active involvement. They also include a positive identification with the problems of the organization. Civic virtue is manifested through active participation in meetings, knowledge 
of the activities of the organization, and talking discretely outside the company, for instance, in order to protect its activities and image.

4) Courtesy - discretionary behaviors directed at preventing conflicts with other members of the organization. It is a helpful behavior that aims to prevent the occurrence of problems. It also encompasses civility, good manners, and politeness. Courtesy might be manifested in many ways from verbal civility to providing other employees with information that is necessary for their work.

5) Sportsmanship - willingness of the employee to tolerate conditions of work that are less than ideal without complaining and exaggerating problems. Sportsmanship is also about submitting to changes in the organization, even though the employee does not agree with them, or they will result in a worsening of his or her conditions of work. By reducing the number of complaints from employees' sportsmanship results in saving time and energy.

The five-dimensional model of organizational citizenship behavior has been confirmed in scientific research. Some scholars, however, propose some new dimensions or components, such as organizational loyalty, initiative, or self-development. Some authors also point to the fact that dimensions of organizational citizenship behaviors are highly correlated among each other, which can result in their strong multicollinearity and, in consequence, the unidimensionality of the construct of OCB. This view is not shared by some scholars. For instance, Williams and Anderson (1991) claim that five dimensions could be divided into two factors: OCB directed at other people (altruism and courtesy) and OCB directed at the organization (conscientiousness, civic virtue, and sportsmanship).

The measure of OCB was proposed by Podsakoff, MacKenzie, Moorman, and Fetter (1990). It was based on the definitions of components of OCB by Organ (1988), as discussed above. Definitions were used to create items measuring each of the components. The list was then presented to ten scholars for Q-sorting. Each of the academics was presented with the definitions of five dimensions and was asked to attribute items to components which, in their opinion, matched the item in the best way. Scholars could also attribute items to a sixth category marked as "other" in case they thought that they do not fit any of the components. The final list of items included only those that were attributed by at least $80 \%$ of the scholars. The items were answered on a 7-point Likert scale.

Organizational citizenship behaviors might be the result of the application of high performance solutions, especially regarding human resource management. Godard (2001) claims that this relationship is non-linear, and the highest OCBs are achieved with a medium level of high performance work practices. Sun, Aryee, and Law (2007) point to OCB as a mediating 
factor between HPWP and organizational performance. Also, analysis of the content of HPO factors allows one to assume the positive effect of OCBs. For instance, conscientiousness should be strongly influenced by openness and action orientation, management and workforce quality. Civic virtue is assumed to be the result of openness and action orientation (frequent dialogue between managers and employees, frequent communication), and long-term orientation (secure workplace). Therefore, it can be hypothesized:

H5. High performance indicators positively influence organizational citizenship behaviors.

The positive effect of OCB on organizational performance is part of the definition of OCB and the review of early evidence on this relationship is presented by Podsakoff and MacKenzie (1997). They claim that the impact of altruism is stronger than that of sportsmanship and civic virtue. Positive influence is also reported in more recent works, although some authors point to a possible negative effect (Bolino, Klotz, Turnley, \& Harvey, 2013). Also, Bryl (2018) points to the fact that HR-based resources have an impact on performance. Taking all of the above into consideration, it can be hypothesized that:

H6. Organizational citizenship behaviors positively influence organizational performance.

Hypotheses $\mathrm{H} 5$ and $\mathrm{H} 6$ taken together allow one to assume that OCBs are a mediator in the relationship between high performance indicators and organizational performance, therefore:

H7. Organizational citizenship behaviors mediate the relationship between high performance indicators and organizational performance.

Hypotheses $\mathrm{H} 4$ and $\mathrm{H} 7$ are contradictory and also compete with hypothesis $\mathrm{H} 1$. That situation is deliberate and is aimed at measuring which of the relationships between high performance indicators and organizational performance is stronger: direct one, mediation by entrepreneurial orientation, or mediation by organizational citizenship behaviors. The conceptual framework is presented in Figure 1. 


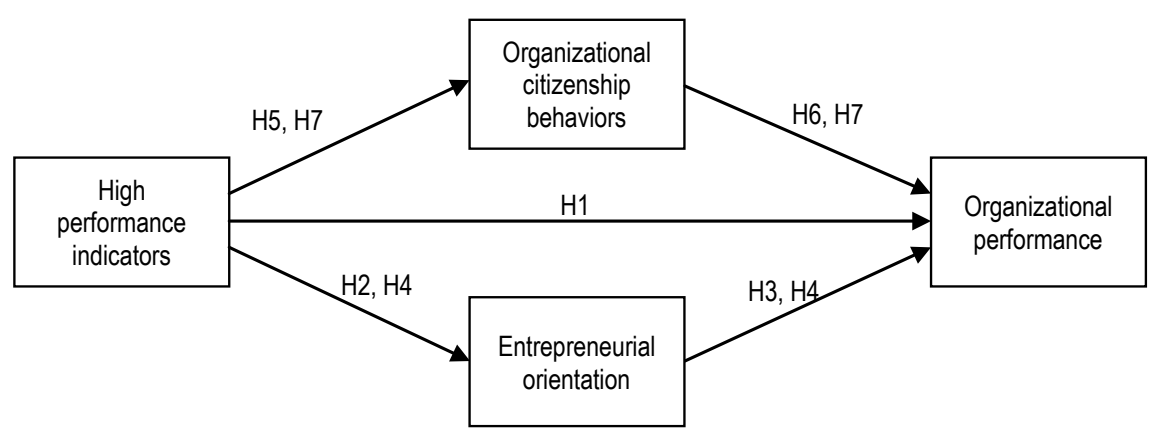

Figure 1. Conceptual framework

\section{METHOD}

\section{Research design and sample}

The research was carried out in a cross-sectional design on a random and representative sample of 406 enterprises using the technique of personal interview (CAPI). In each enterprise, two people were surveyed: a senior manager (owner-manager or member of the board if possible) and the direct subordinate of that person. Sampling was random, and the sample frame was the database of Polish enterprises employing from 50 to 1000 employees. A random automated selection from the sample frame was conducted. The choice to exclude small and very large enterprises was caused by the nature of researched relationships. In small organizations, the relationships are mostly informal, and high performance indicators are very rarely adapted. Contrary, in very large companies relations, are highly formalized, and data on organizational performance is not reliable. A couple of industries were excluded from the sampling: section A (PKD - Polish Classification of Activity) - farming, forestry, hunting and fishing, section $B$ - mining and extraction of natural resources, section $\mathrm{E}$ - water supply, sewage and waste management, recultivation, section $\mathrm{O}$ - public administration, national defense, obligatory social security, section Q-healthcare and social support, section T-households employing workers, households producing goods and serving services for their own needs, section $U$ - exterritorial organizations and groups. Organizations in those sections run specific activities that could distort the research results. The average age of the companies in the sample was 21 years $(S D=15)$, and the average employment was 172 employees $(S D=230)$. 


\section{Variables and measures}

To measure high performance factors, the measure created by De Waal (2012) was used. Each of the dimensions was measured using three questions. The established convention of factor analysis was used to confirm the dimensionality of the constructs and Cronbach's alpha statistic to test the reliability of the scales. The following Cronbach alpha reliability coefficients were calculated: continuous improvement (.877), openness and action orientation (.762), management quality (.836), workforce quality (.825), long-term orientation (.791). To measure organizational citizenship behaviors, the scale developed by Podsakoff, MacKenzie, Moorman, and Fetter (1990) was used. Three items measure altruism (.839), four items measure conscientiousness (.859), four items measure civic virtue (.834), four items measure courtesy (.789), and four items measure sportsmanship (.836). Entrepreneurial orientation was measured using Kreiser, Marino, and Weaver's (2002) scale with three dimensions: innovativeness (three items, .842), proactiveness (three items, .834), risk taking (two items, .833). For high performance factors and entrepreneurial orientation, confirmatory factor analysis was conducted that confirmed the dimensionality of the constructs. However, for further analyses, the dimensions were aggregated to single measures of high performance indicators (HPO) and entrepreneurial orientation (EO). Organizational performance was measured as a mean of five subjective indicators of performance (employment growth, sales growth, market share dynamics, profit, and customer loyalty). The correlation is presented in Table 1.

Table 1. Descriptive statistics and correlations

\begin{tabular}{llllllll}
\hline & Mean & SD & N & OCB & EO & \multicolumn{2}{l}{ Performance } \\
\hline OCB & 4.9501 & .74420 & 406 & 1 & $.254^{* *}$ & $.207^{* *}$ & $.733^{* *}$ \\
EO & 4.1679 & 1.18798 & 406 & $.254^{* *}$ & 1 & $.251^{* *}$ & $.332^{* *}$ \\
Performance & 4.5394 & .80392 & 406 & $.207^{* *}$ & $.251^{* *}$ & 1 & $.362^{* *}$ \\
HPO & 5.3322 & .85571 & 406 & $.733^{* *}$ & $.332^{* *}$ & $.362^{* *}$ & 1 \\
\hline
\end{tabular}

\section{Analytical techniques}

To test the hypotheses, the mediation modeling was chosen. To further test the model, the bootstrapping procedure was used with 200 bootstrap samples and a bias-corrected confidence level at $90 \%$. Structural equation modeling was used to create and test the model, and calculations were performed using SPSS AMOS 25 software. 


\section{RESULTS}

The results of the mediation analysis indicate the direct influence of high performance indicators on organizational performance, a strong impact of high performance indicators on organizational citizenship behaviors and entrepreneurial orientation, a weaker positive influence of entrepreneurial orientation on organizational performance, and a weak negative effect of OCB on organizational performance. The results of the mediation model are presented in Figure 2 and Tables 2-4.

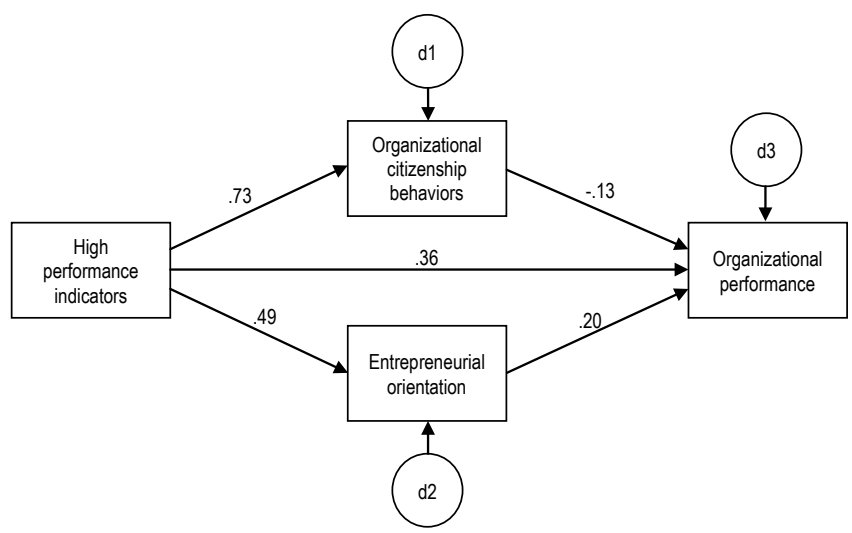

Figure 2. Mediation model with standardized weights

Table 2. Regression weights

\begin{tabular}{|c|c|c|c|c|c|c|}
\hline & & & Estimate & S.E. & C.R. & $\mathbf{P}$ \\
\hline OCB & $<--$ & HPO & .638 & .029 & 21.707 & $* * *$ \\
\hline EO & $<--$ & HPO & .679 & .060 & 11.387 & $* * *$ \\
\hline Performance & $<--$ & OCB & -.139 & .072 & -1.931 & .054 \\
\hline Performance & $<--$ & EO & .137 & .035 & 3.871 & $* * *$ \\
\hline Performance & $<--$ & HPO & .335 & .067 & 4.999 & $* * *$ \\
\hline
\end{tabular}

Further analysis of the research results suggests that all of the relationships in the model are statistically significant except for the relationship between organizational citizenship behaviors and organizational performance. Therefore, high performance indicators affect $\mathrm{OCB}$, EO, and organizational performance, which is also under the influence of EO, but not OCB. Table 3 presents the exact standardized regression weights. 
Table 3. Standardized regression weights

\begin{tabular}{llll}
\hline & & & Estimate \\
\hline OCB & $<---$ & HPO & .733 \\
EO & $<---$ & HPO & .492 \\
Performance & $<---$ & OCB & -.129 \\
Performance & $<---$ & EO & .201 \\
Performance & $<---$ & HPO & .357 \\
\hline
\end{tabular}

Standardized regression weights point to a very strong impact of high performance indicators on organizational citizenship behaviors, a weaker influence of HPO factors on entrepreneurial orientation, and directly on organizational performance. Tables 4 presents standardized total, direct, and indirect effects.

Table 4. Standardized total, direct, and indirect effects

\begin{tabular}{lccc}
\hline \multicolumn{3}{c}{ Standardized total effects } \\
\hline EO & HPO & EO & OCB \\
OCB & .492 & .000 & .000 \\
Performance & .733 & .000 & .000 \\
& .362 & .201 & -.129 \\
\hline & \multicolumn{4}{c}{ Standardized direct effects } \\
EO & HPO & .000 & OCB \\
OCB & .492 & .000 & .000 \\
Performance & .733 & .201 & .000 \\
\hline & .357 & Standardized indirect effects & -.129 \\
\hline & HPO & EO & OCB \\
EO & .000 & .000 & .000 \\
OCB & .000 & .000 & .000 \\
Performance & .005 & .000 & .000 \\
\hline
\end{tabular}

As can be seen, almost the entire total (direct and indirect) effect of high performance indicators on organizational performance is explained by direct impact. However, the indirect effect on organizational citizenship behaviors is negative. It is probably statistically insignificant, and therefore the model does not yield results for the indirect impact of high performance indicators on organizational performance mediated by entrepreneurial orientation. The statistical significance of the obtained results was tested by bootstrapping. For 
this procedure, the number of bootstrap samples was set at 2000, and the biascorrected confidence level was set at $90 \%$. The statistical significance was then tested in a bias-corrected percentile method by comparing the lower bounds and upper bounds in standardized total effects, standardized direct effects, and standardized indirect effects. The results are presented in Table 5.

Table 5. Standardized total, direct, and indirect effects

\begin{tabular}{|c|c|c|c|}
\hline \multicolumn{4}{|c|}{ Standardized total effects } \\
\hline & HPO & EO & OCB \\
\hline \multicolumn{4}{|c|}{ Lower bounds } \\
\hline EO & .404 & .000 & .000 \\
\hline OCB & .687 & .000 & .000 \\
\hline Performance & .293 & .122 & -.262 \\
\hline \multicolumn{4}{|c|}{ Upper bounds } \\
\hline EO & .553 & .000 & .000 \\
\hline OCB & .768 & .000 & .000 \\
\hline Performance & .421 & .288 & -.011 \\
\hline \multicolumn{4}{|c|}{ Standardized direct effects } \\
\hline & HPO & EO & OCB \\
\hline \multicolumn{4}{|c|}{ Lower bounds } \\
\hline EO & .404 & .000 & .000 \\
\hline OCB & .687 & .000 & .000 \\
\hline Performance & .247 & .122 & -.262 \\
\hline \multicolumn{4}{|c|}{ Upper bounds } \\
\hline EO & .553 & .000 & .000 \\
\hline OCB & .768 & .000 & .000 \\
\hline Performance & .466 & .288 & -.011 \\
\hline \multicolumn{4}{|c|}{ Standardized indirect effects } \\
\hline & HPO & EO & OCB \\
\hline \multicolumn{4}{|c|}{ Lower bounds } \\
\hline EO & .000 & .000 & .000 \\
\hline OCB & .000 & .000 & .000 \\
\hline Performance & -.094 & .000 & .000 \\
\hline \multicolumn{4}{|c|}{ Upper bounds } \\
\hline EO & .000 & .000 & .000 \\
\hline OCB & .000 & .000 & .000 \\
\hline Performance & .107 & .000 & .000 \\
\hline
\end{tabular}


The bootstrapping procedure proves that all of the direct, indirect, and total effects are statistically significant with a confidence level of $90 \%$ except for the indirect impact of high performance indicators on organizational performance. The above results provide full support for hypotheses $\mathrm{H} 1$, $\mathrm{H} 2, \mathrm{H} 3$, and $\mathrm{H} 5$. Hypotheses $\mathrm{H} 6$ and $\mathrm{H} 7$ have to be rejected. Thus, high performance indicators have a direct and indirect effect on organizational performance with entrepreneurial orientation as a mediator. As for hypothesis $\mathrm{H} 4$ that is central to the study considering the assumption of mediation, the research results are inconclusive. That is because the indirect effect of high performance indicators on organizational performance with the mediation of entrepreneurial orientation cannot be established, as the results of indirect effects sum both mediated relationships. For that reason, another model was tested with the exclusion of mediation by OCB. The results are presented in Figure 3 and Tables 6 and 7.

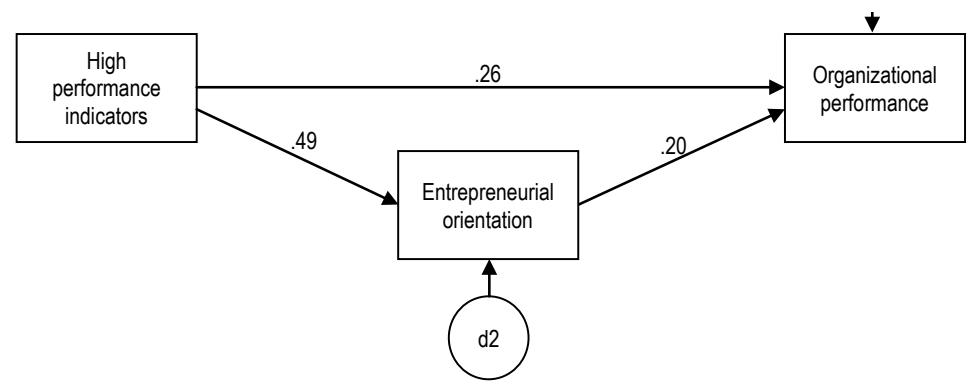

Figure 3. Mediation model with standardized weights.

As can be seen, in the second model, the direct effect of high performance indicators on organizational performance is weaker (the coefficient of 0.26 compared to 0.26 in the first model) than in the first model. That is because the negative indirect effect of $O C B$ is not taken into consideration, and it partly explains the higher direct effect.

Table 6. Standardized indirect effects

\begin{tabular}{lll}
\hline & HPO & EO \\
\hline EO & .000 & .000 \\
Performance & .099 & .000 \\
\hline
\end{tabular}

The standardized indirect effect of high performance indicators on organizational performance with the mediation by entrepreneurial orientation is estimated at the level of .099. As the results of the bootstrapping procedure 
indicate, the indirect impact is statistically significant. However, it is not very strong compared to the direct effect of model 1 and model 2 . Therefore, hypothesis $\mathrm{H} 4$ is supported, but the mediating effect is only partial.

Table 7. Standardized indirect effects (lower and upper bounds)

\begin{tabular}{lll}
\hline & HPO & EO \\
\hline EO & \multicolumn{2}{c}{ Lower bounds } \\
Performance & .000 & .000 \\
& .054 & .000 \\
EO & \multicolumn{2}{c}{ Upper bounds } \\
Performance & .000 & .000 \\
\hline
\end{tabular}

\section{DISCUSSION}

The main question of the study concerned the impact of high performance indicators on organizational performance. Hence, the mediation model was tested, including direct effect and indirect effect with the mediation of two constructs-organizational citizenship behaviorand entrepreneurial orientation. The results provide some valuable insights into complex relationships. First of all, there is a rather strong and statistically significant direct impact of high performance indicators on actual organizational performance. That confirms previous results (e.g., De Waal, 2012; De Waal \& Meingast, 2017; De Waal, Mroueh, \& Schiavo, 2017) that indicate a strong relationship in that regard.

High performance indicators also have a strong positive effect on organizational citizenship behaviors. That also confirms previous research results (Goddard, 2001; Sun, Aryee, \& Law, 2007; Zbierowski, 2012). That result (and comparison to impact of HP factors on EO) is slightly unexpected. That is because high performance frameworks tend to focus on personal and organizational effectiveness while organizational citizenship behaviors in part are about positive behaviors towards co-workers (altruism, courtesy - Podsakoff, MacKenzie, Moorman, \& Fetter, 1990). The deeper analysis of the impact of HPI on OCB reveals that all high performance indicators affect dimensions of OCB. Altruism is under the effect of workforce quality and long-term orientation, for conscientiousness especially important are openness and action orientation, management quality and workforce quality, sportsmanship is created by continuous improvement (negatively) and longterm orientation (positively). Courtesy is dependent on management quality, 
workforce quality, and long-term orientation, and civic virtue is shaped by all high performance indicators.

The effect of high performance indicators on entrepreneurial orientation is also positive and weaker than in terms of OCB. A more in-depth analysis of the effects between dimensions of HPO and EO indicates that continuous improvement and management quality have a positive effect on innovativeness and proactiveness. At the same time, risk taking is shaped positively only by continuous improvement. Generally, the coefficients of the effect of continuous improvement on all three dimensions of entrepreneurial orientation are very high (0.60-0.64).

The impact of entrepreneurial orientation on organizational performance is not very strong, contradictory to the results of previous research (Covin \& Slevin, 1991; Zahra, 1993; Lumpkin \& Dess, 1996; Wiklund \& Shepherd, 2005). This might be due to the fact that the research design was cross-sectional, and the effect of organizational entrepreneurship might have shifted in time, which is discussed in the 'limitations' section of the paper. It can be assumed that with time, the influence of entrepreneurial orientation on organizational performance gains strength, although it is statistically significant from the beginning. Entrepreneurial orientation is, therefore, a good way to increase performance, and mobilized resources yield a return without any delay. The same issue applies to organizational citizenship behaviors, although the situation is a bit different, as in the direct effect of OCB on organizational performance is negative. It is consistent with some previous results (Bolino, Klotz, Turnley, \& Harvey, 2013) that suggest that the immediate effect of $O C B$ on performance might be negative due to the time necessary for positive behaviors to be adapted and aligned with other components of the organization. Generally, it is one of the assumptions of the construct of organizational citizenship behaviors that the accumulated positive effect on performance can be observed in the long run.

The negative impact of $O C B$ on performance has its consequence in the indirect influence of high performance factors on organizational performance with the mediation of OCB that is weak (although statistically significant) and negative. Therefore, attention is focused on entrepreneurial orientation as a possible mediator. To establish the exact strength and significance of that relationship, another mediation model was tested with the exclusion of OCB. It shows that entrepreneurial orientation has a mediating power in the relationship between high performance indicators and organizational performance. However, even though the mediating effect is statistically significant, it is much weaker than a direct effect, so the mediation is an only partial one. 


\section{CONCLUSION}

The results allow the formulation of a couple of recommendations for practice. The introduction of a high performance framework in the organization enables both organizational citizenship behaviors and entrepreneurial orientation to be supported. Which way is more important, taking into consideration internal and external conditions, must be the decision of the company's management. Supporting entrepreneurial orientation also has a positive effect on organizational performance, and therefore it is in the interests of the management of the organization to foster innovativeness, proactiveness, and risk taking. Definitely, supporting those three behaviors will bring benefits for performance. However, it has to be aligned with the strategy of the organization, and, additionally, the positive effect on performance should be expected in the mid- and long-run, as in the short-run, the effect could be not apparent or even negative. High caution is advised in promoting organizational citizenship behaviors. It seems that some of those behaviors are supportive of organizational performance (civic virtue, conscientiousness, sportsmanship) while others might have no or negative effect (altruism, courtesy). In both cases (entrepreneurial attention, organizational citizenship behavior), the effect of those behaviors on organizational performance should be continuously monitored and assessed.

The study has a few limitations. The research design that was applied in the study was a cross-sectional design, and all data was gathered at one point in time. It is not the most suitable design to test complex relationships that can be lagged in time, like for example, the impact of organizational citizenship behaviors and entrepreneurial orientation on organizational performance. That result could probably be observed after a certain time, such as 1-3 years. Therefore it is difficult to draw conclusions based on cross-sectional design results. Another limitation concerns the aggregation of dimensions into constructs. It refers to almost all constructs under research: high performance indicators, entrepreneurial orientation, and organizational citizenship behaviors. That procedure was performed to avoid the overcomplication of the model; however, it does have its disadvantages. Mainly, it does not allow one to measure the effects between separate dimensions and does not allow one to draw specific and detailed conclusions. For instance, in the present study, what the exact impact of the separate high performance factors is on the dimensions of organizational citizenship behavior cannot be observed. This would be very interesting considering the strength of the relationship between those two constructs. Finally, as the constructs bear similar meaning, some collinearity and tautology among them could be expected. That especially concerns high performance indicators and entrepreneurial 
orientation as HPI might partly encompass EO. However, high performance indicators refer to practices that are employed in the organization, while entrepreneurial orientation relates to actions that are undertaken.

My suggestion for future research partly addresses the mentioned limitations. To truly confirm the existence of causal effects, some stronger research designs should be applied, like a longitudinal design or at least a cross-sectional design with a time lag for performance measurement. Also, future research could focus on individual dimensions of the constructs that could bring interesting results by uncovering the complex relationships existing among components of researched constructs. Moreover, as the current study does not take into consideration the possible interplay of organizational citizenship behaviors and entrepreneurial orientation, that path could also be explored in future studies.

\section{Acknowledgment}

The research was carried out within the research project 2014/13/B/ HS4/01618 funded by the National Science Centre, Poland.

\section{References}

Bolino, M. C., Klotz, A. C., Turnley, W. H., \& Harvey, J. (2013). Exploring the dark side of organizational citizenship behavior. Journal of Organizational Behavior, 34, 542-559. http://dx.doi.org/10.1002/job.1847

Brief, A. P., \& Motowidlo, S. J. (1986). Prosocial organizational behavior. Academy of Management Review, 11, 710-725. http://dx.doi. org $/ 10.2307 / 258391$

Bryl, Ł. (2018). Human capital orientation and financial performance. A comparative analysis of US corporations. JournalofEntrepreneurship, Management and Innovation, 14(3), 61-86. https://doi.org/10.7341/20181433

Brockhaus, R. (1980). Risk taking propensity of entrepreneurs. Academy of Management Journal, 23, 509-520. http://dx.doi.org/10.5465/255515

Busenitz, L. W. (1999). Entrepreneurial risks and strategic decision making. The Journal of Applied Behavioral Science, 35, 325-340. http://dx.doi. org/10.1177/0021886399353005

Cameron, K. S. (2008). Positive Leadership. Strategies for Extraordinary Performance. San Francisco: Berrett Koehler.

Cameron, K. S., Dutton, J. E., \& Quinn, R.E. (2003). Positive Organizational Scholarship. Foundations of a New Discipline. San Francisco: BerrettKoahler Publishers, Inc.

Collins, J. C., \& Porras, J. I. (1994). Built to Last. Successful Habits of Visionary Companies. New York: Harper Business. 
Collins, J. C. (2001). Good to Great: Why Some Companies Make the Leap... and Others Don't. New York: Harper Business.

Covin, J. G., \& Slevin, D. P. (1988). The influence of organization structure on the utility of an entrepreneurial top management style. Journal of Management Studies, 25(3), 217-234. http://dx.doi.org/10.1111/j.1467-6486.1988.tb00033.x

Covin, J. G., \& Slevin, D. P. (1989). Strategic management of small firms in hostile and benign environments. Strategic Management Journal, 10, 75-87. http://dx.doi.org/10.1002/smj.4250100107

Covin, J. G., \& Slevin, D. P. (1991). A conceptual model of entrepreneurship as firm behavior. Entrepreneurship Theory and Practice, 16(1), 7-25. http:// dx.doi.org/10.1177/104225879101600102

De Waal, A. A. (2010). Achieving high performance in the public sector: What needs to be done? Public Performance \& Management Review, 34(1), 81-103. http://dx.doi.org/10.2753/PMR1530-9576340105

De Waal, A. A. (2012). Characteristics of high performance organizations. Business Management and Strategy, 3(1), 28-45. http://dx.doi. org/10.1108/17515630710684178

De Waal, A., van Nierop, E., \& Sloot, L. (2017). Analysing supermarket performance with the high-performance organization framework. International Journal of Retail \& Distribution Management, 45(1), 5770. http://dx.doi.org/10.1108/IJRDM-03-2016-0042

De Waal, A., \& Heijtel, I. (2017). Developing a change approach for the transition to a high performance organization. Measuring Business Excellence, 21(2), 101-116. http://dx.doi.org/10.1108/MBE-03-2016-0015

De Waal, A., \& Meingast, A. (2017). Applying the high performance organization framework in the horticulture and greenhouse sector. Measuring Business Excellence, 21(2), 136-151. http://dx.doi.org/10.1108/MBE-05-2016-0028

De Waal, A., Mroueh, M., \& Schiavo, L. (2017). Analyzing performance in the UAE manufacturing industry using the high performance organization framework. Middle East Journal of Business, 12(1), 3-11. http://dx.doi. org/10.1002/joe.21561

Dess, G. G., Lumpkin, G. T., \& McGee, J. E. (1999). Linking corporate entrepreneurship to strategy, structure, and process: Suggested research directions. Entrepreneurship Theory \& Practice, 23(3), 85-102. http:// dx.doi.org/10.1177/104225879902300306

Freiling, J., \& Schelhowe, Ch. L. (2014). The impact of entrepreneurial orientation on the performance and speed of internationalization. Journal of Entrepreneurship, Management and Innovation, 10(4), 169199. http://dx.doi.org/10.7341/20141047

Holbeche, L. (2005). The High Performance Organization. Creating Dynamic Stability and Sustainable Success. Oxford: Elsevier/Butherworth Heinemann.

Khandwalla, P. N. (1977). The Design of Organizations. New York: Harcourt Brace Janovich.

Kreiser, P. M., Marino L., \& Weaver, K. M. (2002). Assessing the psychometric properties of the entrepreneurial orientation scale: A multi-country 
analysis. Entrepreneurship Theory and Practice, 26(4), 71-94. http:// dx.doi.org/10.1177/104225870202600405

Lawler, E. E. III, \& Worley, C. G. (2006). Built to Change. How to Achieve Sustained Organizational Effectiveness. San Francisco: Jossey-Bass.

Light, P. C. (2005). The Four Pillars of High Performance. How Robust Organizations Achieve Extraordinary Results. New York: McGraw-Hill.

Sun, L.-Y., Aryee, S., \& Law, K. S. (2007). High-performance human resource practices, citizenship behavior, and organizational performance: A relational perspective. Academy of Management Journal, 50(3), 558577. http://dx.doi.org/10.5465/amj.2007.25525821

Lumpkin, G. T., \& Dess G. G. (2001). Linking two dimensions of entrepreneurial orientation to firm performance: The moderating role of environment and industry life cycle. Journal of Business Venturing, 16(5), 429-451. https://doi.org/10.1016/S0883-9026(00)00048-3

Lumpkin, G. T., \& Dess, G. G. (1996). Clarifying the entrepreneurial orientation construct and linking it to performance. Academy of Management Journal, 21(1), 135-172. http://dx.doi.org/10.2307/258632

Miller, D., \& Friesen, P. H.(1982). Innovation in conservative and entrepreneurial firms: Two models of strategic momentum. Strategic Management Journal, 3(1), 1-25. http://dx.doi.org/10.1002/smj.4250030102

Miller, D., \& Le Breton-Miller, J. (2005). Managing for Long Run. Lessons in Competitive Advantage from Great Family Businesses. Boston: Harvard Business School Press.

Mintzberg, H. (1973). Strategy-making in three modes. California Management Review, 16(2), 44-53. http://dx.doi.org/10.2307/41164491

Nam, D., Parboteeah, K., Cullen, J., \& Johnson, J. (2014). Cross-national differences in firms undertaking innovation initiatives: An application of institutional anomie theory. Journal of International Management, 20(2), 91-106. http://dx.doi.org/10.1016/j.intman.2013.05.001

Organ, D. W. (1988). Organizational Citizenship Behavior. The Good Soldier Syndrome. Lexington: Lexington Books.

Palich, L. E., \& Bagby, D.R. (1995). Using cognitive theory to explain entrepreneurial risk-taking: Challenging conventional wisdom. Journal of Business Venturing, 10(6), 425-438. http://dx.doi.org/10.1016/08839026(95)00082-J

Peters, T. J., \& Waterman, R. H. (1982). In Search of Excellence: Lessons from America's Best-Run Companies. New York: Harper \& Row.

Podsakoff, P. M., \& MacKenzie, S. B. (1997). Impact of organizational citizenship behavior on organizational performance: A review and suggestion for future research. Human Performance, 10(2), 133-151. http://dx.doi. org/10.1207/s15327043hup1002_5

Podsakoff, P. M., MacKenzie, S. B., Moorman, R. H., \& Fetter, R. (1990). Transformational leader behaviors and their effects on followers' trust in leader, satisfaction, and organizational citizenship behaviors. 
Leadership Quarterly, 1(2), 107-142. http://dx.doi.org/10.1016/10489843(90)90009-7

Schumpeter, J. A. (1934). The Theory of Economic Development. Cambridge: Harvard University Press.

Steensma, H. K., Marino, L. D., Weaver, K. M., \& Dickson, P.H. (2000). The influence of national culture on the formation of technology alliances by entrepreneurial firms. Academy of Management Journal, 43, 951-973. http://dx.doi.org/10.5465/1556421

Stevenson, H. H., \& Jarillo, J. (1990). A paradigm of entrepreneurship: Entrepreneurial management. Strategic Management Journal, 11, 1727. http://dx.doi.org/10.1007/3-540-48543-0_7

Wiklund, J., \& Shepherd, D. (2005). Entrepreneurial orientation and small business performance: A configurational approach. Journal of Business Venturing, 20(1), 71-91. http://dx.doi.org/10.1016/j.jbusvent.2004.01.001 Williams, L. J., \& Anderson, S. E. (1991). Job satisfaction and organizational commitment as predictors of organizational citizenship and in-role behaviors. Journal of Management, 17(3), 601-617. http://dx.doi. org/10.1177/014920639101700305

Zahra, S.A. (1993). Environment, corporate entrepreneurship, and financial performance: A taxonomic approach. Journal of Business Venturing, 8, 319-340. http://dx.doi.org/10.1016/0883-9026(93)90003-N

Zarei, M. (2017). Entrepreneurial tournaments: Towards disclosing the rivalry process among corporate entrepreneurs. Journal of Entrepreneurship, Management and Innovation, 13(2), 33-57. http:// dx.doi.org/10.7341/20171322

Zbierowski, P. (2012). Orientacja Pozytywna Organizacji Wysokiej Efektywności. Warszawa: Wolters Kluwer.

\begin{abstract}
Abstrakt
Poszukiwanie źródeł wysokiej efektywności jest jednym z najbardziej trwałych tematów w nauce o zarzqdzaniu, który zaowocował stworzeniem znaczq̨cej liczby modeli na przestrzeni dziesięcioleci. Celem opracowania jest zbadanie czy wpływ czynników wysokiej efektywności (high performance organization (HPO)) na faktycznq efektywność organizacji jest mediowany przez obywatelskie zachowania organizacyjne (organizational citizenship behavior (OCB)) oraz orientację przedsiębiorczq (entrepreneurial orientation (EO)). Wyniki wcześniej prowadzonych badań wskazuja, że model czynników wysokiej efektywności odpowiada na pytanie 'co' robiq liderzy efektywności, ale nie odpowiada na pytanie 'jak' to robiq, sugerujqc efekt pośredniczenia. Obecny artykuł ma na celu sprawdzenie który z konstruktów (OCB czy EO) pośredniczy w tej relacji. Hipotezy zostały testowane przy wykorzystaniu badań przekrojowych na losowo dobranej i reprezentatywnej próbie 406 przedsiębiorstw. Badania zostały przeprowadzone metodq wywiadu bezpośredniego (CAPI). Ugruntowane w literaturze narzędzia badawcze posłużyły do pomiaru obywatelskich zachowań organizacyjnych, orientacji przedsiębiorczej, czynników wysokiej efektywności i efektywności organizacyjnej. Teo-
\end{abstract}


retyczny model zależności został poddany weryfikacji przy wykorzystaniu modelowania równań strukturalnych. Wyniki badań wskazujq na to, że istnieje silny bezpośredni wpływ czynników wysokiej efektywności na efektywność organizacji. Ponadto, istnieje silny pozytywny wpływ czynników wysokiej efektywności na organizacyjne zachowania obywatelskie i orientację przedsiębiorczq. Wpływ tych dwóch konstruktów na efektywność organizacji jest jednak niski i, w przypadku organizacyjnych zachowań obywatelskich, negatywny. Prowadzi to do wniosku, że bezpośredni wpływ czynników wysokiej efektywności jest silniejszy, mimo że mediacja za pośrednictwem orientacji przedsiębiorczej jest istotna statystycznie. Artykuł wnosi wkład do debaty naukowej na co najmniej trzy sposoby. Po pierwsze, potwierdza duże znaczenie czynników wysokiej efektywności w kreowaniu sukcesu przedsiębiorstwa. Po drugie, wskazuje na fakt, że orientacja przedsiębiorcza jest częściowym pośrednikiem w tej relacji. Po trzecie, ujawnia bardzo duże znaczenie czynników wysokiej efektywności we wspieraniu organizacyjnych zachowań obywatelskich. Wyniki badań pozwalajq również na sformułowanie rekomendacji praktycznych. Dotyczq one głównie wspierania postaw obywatelskich, orientacji przedsiębiorczej oraz poprawy efektywności organizacji poprzez umiejętne zarzq̨dzanie czynnikami wysokiej efektywności. Przeprowadzone badania sq nowatorskie w zakresie ujęcia obywatelskich zachowań organizacyjnych oraz orientacji przedsiębiorczej jako pośredników w relacji między czynnikami wysokiej efektywności i sukcesem organizacji, podobne podejście nie było testowane w przeszłości.

Słowa kluczowe: czynniki wysokiej efektywności, orientacja przedsiębiorcza, organizacyjne zachowania obywatelskie

\section{Biographical note}

Przemysław Zbierowski is an associate professor at University of Economics in Katowice. His research interests focus on entrepreneurship, positive organizational scholarship, positive psychology and organizational behavior. He is an author of over 150 academic papers. He has been a leader of four externally funded projects and since 2011 has been the national team leader of the Global Entrepreneurship Monitor project. Currently, he performs a Maria SkłodowskaCurie fellowship awarded by the European Commission at King's College London.

\section{Conflicts of interest}

The author declares no conflict of interest.

\section{Citation (APA Style)}

Zbierowski, P. (2020). The mystery of high performance - mediation by entrepreneurial orientation and organizational citizenship behavior. Journal of Entrepreneurship, Management and Innovation, 16(2), 67-91. https://doi.org/10.7341/20201623 